\title{
Foster Carers' Perspectives about Contact in Portugal and Spain
}

\author{
Paulo Delgado ${ }^{1}$, Isabel M. Bernedo Muñoz ${ }^{2}$, João M. S. Carvalho ${ }^{3,4}$, María D. Salas Martínez ${ }^{2}$, Miguel Ángel \\ García-Marín $^{5}$ \\ ${ }^{1}$ Centre for Research and Innovation in Education (inED), Porto Polithecnic, Portugal \\ ${ }^{2}$ Developmental and Educational Psychology Department, University of Málaga, Spain \\ ${ }^{3}$ CICS.NOVA.UMinho \\ ${ }^{4}$ REMIT-Universidade Portucalense \\ ${ }^{5}$ Social Psychology, Social Work, Social Anthropology and East Asian Studies, University of Málaga, Spain \\ Correspondence: Paulo Delgado, Escola Superior de Educação do Politécnico do Porto, R. Dr. Roberto Frias 602, \\ 4200-465 Porto, Portugal.
}

Received: September 2, 2019

Accepted: October 10, $2019 \quad$ Available online: October 28, 2019

doi:10.11114/ijsss.v7i6.4502

URL: https://doi.org/10.11114/ijsss.v7i6.4502

\begin{abstract}
This study aims at comparing the nature and processes of contact between children in foster care and their birth families; the relationship between the existence and quality of contact and foster carers' burden; and the relationship between the existence or not of contact and the existence of reunification plans. Following a quantitative approach, data have been collected in Portugal and Spain from foster carers and professionals using questionnaires and Zarit's Carer scale. The results show that the existence of contact is not related to carers' burden or stress, but there is an association between contact and reunification plans. As a consequence, several implications to practice are presented.
\end{abstract}

Keywords: contact visits, cross-national comparison, foster care, foster carers' burden, reunification

\section{Introduction}

Contact between foster children and their birth families is important for their relationship and sense of belonging and wellbeing (Fawley-King et al., 2017). Contact might have a positive impact on foster child' s development and on placement stability (Osborn \& Delfabbro, 2009; Sen \& Broadhurst, 2011; Ward, Munro, \& Dearden, 2006). Contact is also fundamental for foster carers, who are facing the challenge to connect and stay connected with foster children's parents and other family members. In addition, contact is also a substantive topic for professionals because they aim to establish harmonious and good relationships between all parties involved (Morrison et al., 2011; Sen \& McCormack, 2011). In addition, contact is important at a decision level for institutions and policymakers, who are responsible for organizing support services within an inclusive framework (Delgado et al., 2016; López \& Del Valle, 2016).

It is important for foster children to maintain contact with their birth family when this is considered to be in the child's best interests. Contact can play an important role in maintaining or recovering the foster child's attachment to their birth family, bring a greater sense of continuity to the child's life story and to the process of identity development, and enhance the psychological well-being of the foster child (Coakley, 2013; McWey, Acock, \& Porter, 2010). In addition, such contact may serve to underpin the decisions made by social workers in relation to the progress that is being made, and it can also help to maintain the prospect of the child returning to live with the biological family (Sinclair, 2005).

Despite the importance of contact for all parties involved, contact can be emotionally distressing for children (Carvalho \& Delgado, 2014; Howe \& Steele, 2004; Osborn \& Delfabbro, 2009). In this case, the absence of contact might be preferred over problematic contact.

Because of the complexities and consequences, contact in foster care, specially visits, have been the subject of discussion and the topic of research in diverse contexts. The current study aims to present and explore the main outcomes on contact obtained in research projects developed in Portugal (Delgado, Carvalho, \& Pinto, 2017) and Spain (Salas et al., 2016). The option of comparing different systems, bearing in mind the country's explicit socio-cultural characteristics and policies, aims at targeting what is unique in each country and what can be similar, independently of country context, in order to take advantage of the learning potential that diversity can provide. 
The type of contact focused in those studies are visits. Face-to-face meetings are distinguished from other forms of contact due to their relevance to children and adults involved (Neil \& Howe, 2004).

Table 1 briefly describes Foster Care in the two countries and how contact is conceived in each one.

Table 1. Foster Care in Portugal and Spain

\begin{tabular}{|c|c|c|}
\hline Characteristics & Portugal & Spain \\
\hline Foster Care formal existence & Since 1979 & Since 1978 \\
\hline Children in out-of-home care & $\begin{array}{l}8,175 \text { children }- \text { around } 0.4 \% \text { of the total } \\
\text { population of children }\end{array}$ & $\begin{array}{l}33,745 \text { children, which represents } 0.41 \% \text { of } \\
\text { the total population of children }\end{array}$ \\
\hline Children in Foster Care & $3.1 \%$ & $\begin{array}{l}58.2 \% \text { of children are in family foster care } \\
\text { and the rest }(41.8 \%) \text { are in residential care }\end{array}$ \\
\hline Types of Foster Care & Short or long-term ${ }^{(3)}$ & Short or long term ${ }^{(4)}$ \\
\hline Foster Care priority & For children up to 6 years old ${ }^{(5)}$ & $\begin{array}{l}\text { Priority to family foster care over other } \\
\text { forms of care such as residential care }{ }^{(6)}\end{array}$ \\
\hline Adoption from Foster Care & Yes, formally since 2015 & $\begin{array}{l}\text { Adoption by foster parent only happens in } \\
\text { very few specific cases }\end{array}$ \\
\hline Contact definition & $\begin{array}{l}\text { An essential right of the child, that in some cases } \\
\text { might not be possible by judicial decision }\end{array}$ & $\begin{array}{l}\text { Contacts are face to face meetings, } \\
\text { according to the children right to have } \\
\text { regular contact with their parents, and only } \\
\text { if this measure under judicial decision helps } \\
\text { to the child's well-being }\end{array}$ \\
\hline
\end{tabular}

(1) Foster Care consider only families without blood ties (non-kinship care)

(2) Ministerio de Sanidad, Servicios Sociales e Igualdad (2017)

(3) $74 \%$ of children and young people in foster families have been in care longer than 4 years (Instituto da Segurança Social, 2017)

(4) The majority of foster care placements in Spain are permanent (66.6\%)

(5) Amendment of the Law on Protection of Children and Young People in Danger, carried out by Law $142 / 2015$ of September $8^{\text {th }}$.

(6) Law 1/1996, Law 26/2015

The only study carried out in Portugal about contact in foster care (Delgado et al., 2016) has led to the following main conclusions: (i) the importance of including a topic about contact with birth parents, including its process management, in foster carers' training; (ii) the need to develop specialized supervision that closely monitors the context and progress of the visits on a regular base; (iii) and the need to adjust the visit plan to each specific case, depending on specific characteristics such as parents' place of residence and professions, in order to promote their compliance with visit schedule.

In Spain, there is a great heterogeneity in the policies and practices that regulate family foster care and visits. Usually, visits are held at meeting points of foster care agencies. These visits can vary in duration, frequency, degree of supervision and number of family members present at the visit. This heterogeneity shows the need to establish unified criteria to optimize the course of these visits, improve the training of social workers who follow up, and provide better support and preparation for all parties involved (birth families, foster families and foster children) (Fuentes et al., 2018). In Spain, a high proportion of foster children have no contact visits with either of their birth parents. In several cases, this is due to Child Protection Services' beliefs that visits could be contrary to the child's well-being. In fact, some biological families that are allowed to have contact do not show up at arranged visits established by the Child Protection Services (Del Valle et al., 2008; Jiménez \& Palacios 2009; Salas et al., 2016).

In this context, this study aims at comparing the nature and processes of contact between children in foster care and their birth families; the relationship between the existence and the quality of contact and foster carers' burden; and the relationship between the existence or not of contact and the existence of reunification plans.

\section{Methodology}

Following a quantitative approach, this article presents findings about the nature, frequency and associated factors of contact in foster care in Portugal and Spain. Source data have been collected from foster carers and professionals.

\subsection{Samples}

\subsubsection{Portuguese Samples}

The Portuguese data is derived from two distinct samples. The first sample consists of 132 children and young people in 
foster care between 5 and 17 years old from the district of Porto (Table 2), accounting for $36 \%$ of all children and young people in family foster care in Portugal (Instituto de Segurança Social, 2017). The children came from 98 birth families and are placed in 90 foster families. Only a minority $(19.8 \%)$ of the foster children had stayed in at least one other foster family or residential care before the current placement. All the children and young people are in non-kinship care. The second sample consists of a random sample of 52 children of the first sample that was collected to evaluate more deeply the carers' perception about, their feelings in the beginning of contact, its evolution, consequences to the child, and to measure carers' burden.

Table 2. Characteristics of the samples

\begin{tabular}{|c|c|c|c|c|c|}
\hline Samples & $\begin{array}{c}\text { Total } \\
\text { Children }\end{array}$ & $\begin{array}{c}\% \\
\text { Female }\end{array}$ & $\begin{array}{c}\% \\
\text { Male }\end{array}$ & $\begin{array}{c}\text { Age } \\
\text { (years) }\end{array}$ & $\begin{array}{c}\text { Mean time in current foster } \\
\text { placement } \\
\text { (years) }\end{array}$ \\
\hline Portugal (1) & 138 & 37.1 & 62.9 & $\begin{array}{l}M=13.15 \\
S D=3.05 \\
R=5 \text { to } 17 \\
M=14.29\end{array}$ & $\begin{aligned} \mathrm{M} & =6.76 \\
\mathrm{SD} & =4.94\end{aligned}$ \\
\hline Portugal (2) & 52 & 48.1 & 51.9 & $\begin{array}{c}\mathrm{SD}=4.16 \\
\mathrm{R}=5 \text { to } 17\end{array}$ & N.A. \\
\hline Spain & 104 & 53.8 & 46.2 & $\begin{array}{c}\mathrm{M}=11 \\
\mathrm{SD}=3.2 \\
\mathrm{R}=5 \text { to } 17\end{array}$ & $\begin{aligned} \mathrm{M} & =3.7 \\
\mathrm{SD} & =2.5\end{aligned}$ \\
\hline
\end{tabular}

$\mathrm{M}=$ mean; $\mathrm{SD}=$ Standard deviation; $\mathrm{R}=$ Range; N.A. = Not available

\subsubsection{Spanish Sample}

The Spanish sample comprised 104 non-kinship foster children between 5 and 17 years old in long-term foster care (Table 2). The children came from 80 birth families and are placed in 86 foster families. The majority of the foster children had experienced another placement before they entered their current foster family, of which $92.3 \%$ resided in residential care, and $16.3 \%$ in family foster. Only $1 \%$ (one case) of the children resided in two previous placements before their current placement in family foster care.

\subsection{Instruments}

Prior to conducting the studies, written informed consent was obtained from the child protection agencies and institutions and the foster carers in the two countries. Data was treated with confidentiality, maintaining the anonymity of participants, with the approval of the ethics boards of all institutions. Table 3 shows the characteristics of the instruments that were used in the two countries.

Table 3. Characteristics of the instruments

\begin{tabular}{lcc}
\hline \multicolumn{1}{c}{ Foster Families } & Method & Measure to assess the foster carers' burden \\
\hline Portugal & Questionnaire & Zarit's Carer Burden Scale \\
Spain & $\begin{array}{c}\text { Data Collection Sheet } \\
\text { Evaluation of Contact Visits }\end{array}$ & Zarit's Carer Burden Scale \\
\hline
\end{tabular}

\subsubsection{Portuguese Instruments}

A questionnaire was completed by the first sample of 90 foster carers, consisting of questions about: age and gender of the foster child; duration of the placement; frequency of contact; evaluation of foster care regarding its outcomes (success, some positive results, some problems, serious problems); characteristics with respect to the contact between the child or young person and their family; difficulties with respect to contact; and professionals' monitoring of the placement, in terms of communication and support.

The degree of subjective burden experienced by the carers ( 52 females and 37 males) was measured by Zarit's Carer Burden Scale (Zarit, Reever \& Bach-Peterson, 1980). This instrument was adapted from 23 to 21 items, since 2 of them place very particular questions that should not score for the full scale. Several studies have demonstrated the good psychometric properties of this scale (Cerrato et al., 1998; Martín, 1996; Sequeira, 2010). The reliability in our study was acceptable $(\alpha=.67)$. Answers were given on a five-point Likert-type scale. The sum of the scores gives us the value of the 
carers' burden. Thus, the total sum of scores ranges from a minimum of 21 points to a maximum of 105 points, with a higher score representing higher levels of carers' burden. Adapting the proposed levels in the literature, we consider that there is no carers' burden up to 46 points; a slight burden between 47 and 55 points; and intense burden in case of more than 55 points.

\subsubsection{Spanish Instruments}

A data Collection Sheet (Bernedo, Fuentes, \& Salas, 2008a) was the instrument used to record descriptive data regarding the foster children (age, ethnicity, maltreatment, time spent in foster care, characteristics of their birth family, etc.) and their foster carers (age, educational level, type of family, etc.). Social workers also provided additional information about the characteristics of contact visits: frequency, regularity, contact venue, supervision, and the quality and degree of parent-child interaction.

The Evaluation of Contact Visits (Bernedo, Fuentes, \& Salas, 2008b) was designed specifically for the present study. The items are responded to a 5 -point Likert scale $(1=$ totally disagree, $5=$ totally agree). This comprised 9 items and its reliability was good $(\alpha=.73)$.

Zarit Burden Interview (Zarit \& Zarit, 1990) was adapted to assess the degree of subjective burden experienced by foster carers (Del Valle et al., 2008). It comprises 21 items, each of which has five possible response categories (from 1 $=$ not at all to $5=$ very much so). The reliability of the ZBI in the present study was .74. Please see the description above (Portuguese Instruments) about how the total score of the ZBI is calculated and which are the cut-points.

\subsection{Procedures}

\subsubsection{Portuguese Procedures}

The questionnaire was developed by the authors with the participation and approval of the 'Instituto de Segurança Social' (public institution) and 'Mundos de Vida' (private institution). The questionnaire for the foster carers was filled out in the presence of one member of the research team in order to ensure a high number of responses. Data collection took place between October 2013 and March 2014. In April 2014, the study with the second sample of 52 foster care families took place.

\subsubsection{Spanish Procedures}

The descriptive data were collected by face to face interviews with the foster families. This took place between January and July 2011. The social workers provided descriptive information about the contact visits (contact venue, supervision, frequency and regularity), as well as about the quality and degree of interaction between the child and the main contact parent (mother or father) during these visits. These social workers also completed the Evaluation of Contact Visits questionnaire.

\section{Results}

\subsection{Nature and Frequency of Contact}

\subsubsection{Existence of Contact Visits and Type of Visitors}

In Portugal, most children and young people in foster care had contact visits with their family (Table 4), nevertheless the percentage that did not have any visit was still relatively high $(48,36.4 \%)$. With respect to the type of visitors (multiple response), it was the parents, together or separately, that mostly visit the foster child (62 cases: $73.8 \%$ ), which implies that the planning and follow-ups of the contacts must be essentially centred on the parents. In 22 cases, the visits are conducted by other relatives. Table 5 presents the results from multiple responses.

Table 4. Existence of contact visits

\begin{tabular}{llll}
\hline & \multicolumn{3}{c}{ Existence of contact visits } \\
\cline { 2 - 4 } & $Y e s$ & No & $N$ \\
\hline Portugal -1 & $84(63.6 \%)$ & $48(36.4 \%)$ & 132 \\
Spain & $56(53.8 \%)$ & $48(46.2 \%)$ & 104 \\
\hline
\end{tabular}


Table 5. Who does the visits?

\begin{tabular}{|c|c|c|c|c|}
\hline & \multicolumn{2}{|c|}{ Portugal $^{1}$} & \multicolumn{2}{|c|}{ Spain } \\
\hline & Frequency & $\begin{array}{l}\text { Percent } \\
\text { of cases }\end{array}$ & Frequency & $\begin{array}{l}\text { Percent } \\
\text { of cases }\end{array}$ \\
\hline Father and mother together & 16 & 19.5 & 24 & 42.9 \\
\hline Father and mother separately & 12 & 14.6 & 0 & 0 \\
\hline Just the father & 11 & 13.4 & 1 & 1.8 \\
\hline Just the mother & 28 & 34.1 & 31 & 55.4 \\
\hline Other relatives & 35 & 42.7 & $\mathrm{n} / \mathrm{a}$ & $\mathrm{n} / \mathrm{a}$ \\
\hline
\end{tabular}

$\mathrm{n} / \mathrm{a}=$ not available

${ }^{1}$ Multiple responses were possible, meaning that the total percentage of the 'percent of cases' column is more than $100 \%$.

In Spain, of the 104 foster children, only 56 (53.8\%) had contact visits with their birth parents (Table 4). The remaining children (46.2\%) had no contact with either birth parent. Overall (Table 5), 25 children had visits with their father (1 with the father alone and 24 with both parents) and 55 had visits with their mother (31 with the mother alone and 24 with both parents). Sometimes, siblings, aunties, grandparents, or other relatives take part at the visits.

Using a t-test for the percentage differences in contact visits, we find that they are statistically significant $(p<.01)$, showing that in Portugal there is a higher percentage of children with contact visits.

\subsubsection{Visits' Supervision and Venue}

In Portugal, only $8.3 \%$ of the visits (10 cases) were supervised by order of the court of law. Visits occurred primarily in foster homes (45.8\%), but also in other places $(28.3 \%)$, or in birth families' homes $(25.8 \%)$.

In Spain, almost all the contact visits $(95.1 \%)$ were supervised and took place in a contact venue established by the child protection agencies. In the remaining cases, the birth parents were allowed to choose the venue (their own home, the park, etc.). None of the visits took place in the foster carers' home.

\subsection{Relation between Contact and Carers' Burden}

In Portugal, the majority of the carers did not feel burdened (Table 6). Foster carers, both female and male carers, indicated a higher burden in response to the question that concerned their fear for the child's future. There is no statistical significance in both type of carers between the level of burden and the existence of visits (female: $t\left({ }_{50)}=.11 ; p=.913\right.$; male: $t_{(35)}=.59 ; p=.559$ ), or the quality of the contact (female: $F_{(3,31)}=1.955 ; p=.141 ;$ male: $F_{(3,21)}=.998 ; p=.413$ ). However, there is a trade-off between the burden levels in relation to the sex of the carers $(r=-.791 ; p<.001)$ : the higher the score is in women the lower it is in men.

Table 6 . Burden felt by carers

\begin{tabular}{|c|c|c|c|c|c|c|}
\hline \multirow{3}{*}{ Level of pressure } & \multicolumn{4}{|c|}{ Portugal } & \multicolumn{2}{|c|}{ Spain } \\
\hline & \multicolumn{2}{|c|}{ Female carers } & \multicolumn{2}{|c|}{ Male carers } & \multicolumn{2}{|c|}{ Foster carers } \\
\hline & Frequency & Percent & Frequency & Percent & Frequency & Percent \\
\hline Without pressure & 47 & 90.4 & 34 & 91.9 & 94 & 90.4 \\
\hline Mild pressure & 3 & 5.8 & 2 & 5.4 & 9 & 8.7 \\
\hline Intense pressure & 2 & 3.8 & 1 & 2.7 & 1 & 0.9 \\
\hline Total & 52 & 100 & 37 & 100 & 104 & 100 \\
\hline
\end{tabular}

In Spain, the analysis of ZBI scores revealed that $90.4 \%$ of foster carers reported no burden, $8.7 \%$ ( 9 families) experienced mild burden and 1\% (1 family) had high levels of burden (Table 6). The mean ZBI total score was 36.13 (SD $=7.85$; no burden), with a range from 23 to 61 . No statistically significant differences were found between foster carers' burden scores and contact visits.

\subsection{Relation between Reunification Plans and Contact}

In Portugal (Table 7), in the majority of the case (82.4\%), foster carers indicated that there were no plans for reunification. Foster children with contact are those who more often have reunification plans, with statistical significance $\left(\chi_{(1, N=134)}^{2}=6.79, p<.01\right)$.

In Spain, the data offered about reunification showed the confirmed cases of reunification six years after the former study (see Bernedo et al., 2016). Of 13 children who returned to their birth family, 10 maintained the visits during the placement and three did not. These three children returned when they reached adulthood. 
Table 7. Is there a reunification plan?

\begin{tabular}{lccccc}
\hline & \multicolumn{2}{c}{ Portugal } & & \multicolumn{2}{c}{ Spain } \\
\cline { 2 - 3 } \cline { 5 - 6 } & Frequency & Valid Percent & & Frequency & Valid Percent \\
\hline Yes & 15 & 17.6 & & 13 & 8.5 \\
No & 70 & 82.4 & & 91 & 87.5 \\
Missing data & 47 & & & 104 & 100 \\
Total & 132 & 100 & & 104 \\
\hline
\end{tabular}

\section{Discussion}

\subsection{Frequency and Nature of Contact}

This comparative research demonstrated cross-national variations and similarities. The historical evolution of foster care in Portugal and Spain and the intensity in which it is used in these countries may explain the relative low percentage detected in contact visits. Foster carers focus on the integration of the child in their family, revealing a more closed position regarding the relation with social services and the biological family. Nevertheless, in Portugal the percentage of children who have visits is higher, which may be justified by the geographical and socio-economic proximity of the foster families to their families of origin (Delgado et al., 2013). An implication for practice is the necessity to assure, in the near future, that carers became more conscious and informed about their role as a temporary caregiver for the children they take care of. This also involves promoting the contact and the conditions for its preparation, realization and evaluation, in partnership with social workers, which is in accordance with López and Del Valle (2016).

Concerning the actors of the visits, the presence in the visits of the father and of the mother together or only of the mother is greater in Spain. However, there is a greater presence in Portugal in the visits of the two (father and mother) separately, or only the father, which reveals a greater role of the male in the contact with the children fostered. For further research it would be important to compare and explore the division of roles and the way gender influence contact in foster care.

Another finding of this study is that there are contact visits with several members of the biological family. Notwithstanding the central role of birth parents in contact visits, together or separate, we should not forget the role that grandparents, uncles or siblings can play, as pointed out by Whiting and Lee (2003) and Ofsted (2009) and also illustrated in this study.

An interesting difference between the two countries is the number of supervised visits. In Spain, the majority of the visits is supervised. This is in sharp contrast to Portugal, where only about ten percent of the visits is supervised. Maybe the scarce number of professionals involved in child protection agencies explains that contact visits are often unsupervised, making it impossible to promote contact with the carers, the child and, above all, the biological family, that frequently ends up being forgotten as the placement goes on (Delgado et al., 2016). The delegation of responsibilities in the foster family is much more pronounced than in Spain. Once placed, the child is integrated into the foster family and is case is often forgotten by professionals, which can be a threat to children's well-being and at the same time, make forget the importance of their parents' visits. Although the majority of visits are supervised in Spain, foster carers still complain about insufficient monitoring of visits due to a shortage of social workers, the lack of support and preparation given to foster families, children, and birth families regarding contact visits (Fuentes et al., 2018).

This study also showed that supervision of visits is directly related to the venue where they occur. Interestingly, different results were found for the two countries, which indicate the importance of the national and cultural context when studying this topic. In Spain, as the visits take place in places defined by child protection agencies, almost all visits are supervised. The delegation and specialization of tasks allows for on-site monitoring and ongoing evaluation of the established relationship. In Portugal, most visits take place in foster homes or birth families homes, with very few supervised visits. According to Höjer (2009) parents might feel to be in an inferior position in foster carers' home, and experience some difficulties to interact naturally with their children. We must remember that those parents were replaced in their parental role and might feel guilty and lost in carers' home. So, in Portugal, it is essential to find more neutral places to do visits.

\subsection{Relation between Foster Carers' Burden and the Existence of Visits}

Regarding the relationship between the contact and the burden felt by the carers, the two Iberian countries have the same pattern, that is, foster carers did not feel burdened. This pattern may be due to the fact that children were viewed as a part of the family by these carers. From this point of view, foster children did not result in foster carers' burden because they were integrated into the family nucleus in most cases for long periods of time (cf. Table 1).

Although contact on itself was not related to foster carers' stress levels, it appeared that their perception about the 
consequences to them from the existence of contact visits of birth families is negative correlated with female $\left(r_{S}=-.25\right.$; $p=.183)$ and male $\left.\left(r_{S}=-.258\right) ; p=.247\right)$ carer burden level. However, these correlations don't have statistical significance.

Other very important aspect is the issue of sex: the higher the score of burden levels is in women the lower it is in men. This interesting result can be a consequence of a division of responsibilities in the couple, which gives the woman the essential tasks of caring, namely the organization of contact with the family of origin and the management of its consequences on the child. The work of fostering will thus be the main female responsibility, reproducing in the restricted circle of protective activity what happens in a broader scope regarding the uneven division of tasks and occupations within the family.

\subsection{Association between Contact and Reunifications Plans}

With respect to reunification, this study showed that for most children there are no reunification plans. This was more or less the same for both countries.

Portugal presented the largest group of cases for which reunification is planned, but there is no data to confirm whether these plans come true, in contrast to the Spanish study, which has followed up longitudinally and recorded the cases in which reunification did occur. However, it seems that the number of planned reunifications is low in the two countries, with a high number of cases where permanency has to be found within the protection system.

As previously mentioned, the majority of foster care placements in Spain are permanent due to the fact child protection services promote foster children stay with the same foster family (Jiménez \& Palacios, 2009; López et al., 2010). However, this high proportion of permanent foster care also indicate the low tendency of children to return to their birth families, either due to a lack of reunification programs or because of the inefficiency of these plans (Del Valle et al., 2008; López et al., 2010).

The data collected in this international comparative study shows the need to monitor and support the contact after out-of-home placement in an individualized and continuous way, in order to ensure that, as far as possible, this takes place on the best venue, with all important members of the biological family, and at the appropriate frequency in each case, and contribute positively for reunification, if this is feasible. Finally, it should be emphasized that in cases where reunification is planned, most of the children are in contact and this is also the case in the three countries, which is in accordance with previous studies (Coackley, 2013; Fawley-King et al., 2017).

\section{Conclusions}

The current study has several limitations. Due to the cross-national nature of the study, there were certain differences in the samples of the two countries and in the use of instruments and procedures. However, despite these differences, it was still possible to compare the nature and associated factors of contact in Portugal and Spain. We also acknowledge the absence of children's own perspectives in the studies. Unfortunately, it is also impossible to present data about siblings because they weren't collected in any one of the two studies.

Regarding the implications for the practice, the current research indicates that it is necessary to closely support contact. The quality of the parent or other members of the biological family-child interaction during the visits influence the well-being of the child and their affective ties with the relatives, as well as its relationship to the foster family. Other important implication of this study is that contact on itself is not related to foster carers' burden or stress, but quality is, and there is an association between contact and reunification plans.

Given the fact that foster carers' stress is related to placement breakdown, it seems important to carefully monitor the quality of contact visits. Foster care professionals should ask foster carers about the quality of contact visits between the child and the birth family. If there are any signs that contact is problematic, foster care professionals should improve their support, to all parts involved.

More empirical work should be done to understand, in the contexts under study, the impact of a better investment to prepare and support each placement. Training of professionals and carers might increase their knowledge and skills in contact processes. The definition of the policy guidelines that underline the importance of contact, whenever it is possible and desirable, is also strategic in both contexts, always taking in count their cultural and historical environment.

\section{References}

Bernedo, I. M., Fuentes, M. J., \& Salas, M. D. (2008a). Data collection sheet. Unpublished manuscript. Malaga: Department of Developmental and Educational Psychology, University of Malaga.

Bernedo, I. M., Fuentes, M. J., \& Salas, M. D. (2008b). Evaluation of Contact Visits. Unpublished manuscript. Malaga: Department of Developmental and Educational Psychology, University of Malaga. 
Bernedo, I. M., García-Martín, M. A., Salas, M. D., \& Fuentes, M. J. (2016). Placement stability in non-kinship foster care: variables associated with placement disruption. European Journal of Social Work, 19(6), 917-930. https://doi.org/10.1080/13691457.2015.1076770

Carvalho, J. M. S., \& Delgado, P. (2014). Contact in Foster Care: Bridge or Collision Between Two Worlds? Journal of Applied Research on Children, 5(1), Article 10.

Cerrato, I. M., Trocóniz, M. I. F., López, A. L., \& Colodrón, M. S. (1998). La Entrevista de Carga del Cuidador. Utilidad y validez del concepto de carga [The Carer Burden Interview. Usefulness and validity of the burden concept]. Anales de Psicología, 14(2), 229-248.

Coakley, T. (2013). The influence of father involvement on child welfare permanency outcomes: A secondary data analysis. Children and Youth Services Review, 35(1), 174-182. https://doi.org/10.1016/j.childyouth.2012.09.023

Del Valle, J., López, M., Montserrat, C., \& Bravo, A. (2008). El acogimiento familiar en España. Una evaluación de resultados [Foster care in Spain: An assessment of outcomes]. Madrid: Ministerio de Trabajo y Asuntos Sociales.

Delgado, P. (Coord.), Carvalho, J. M. S., Sousa, A., Bertão, A., Moreiras, D., Timóteo, I.,... Oliveira, J. (2016). $O$ contacto no acolhimento familiar. O que pensam as crianças, as famílias e os profissionais [Contact in Foster Care. What professionals, families and children think]. Porto: Mais Leitura.

Delgado, P., Bertão, A., Timóteo, I. O., Carvalho, J. M. S., Sampaio, R., Sousa, A.,..., \& Vieira, I. (2013). Acolhimento Familiar de Crianças. Evidências do presente, desafios para o futuro [Children Foster Care. Present evidences, challenges for the future]. Porto: Livpsic.

Delgado, P., Carvalho, J. M. S., Pinto, V. S., \& Oliveira, J. (2017). Carers and Professionals' Perspectives on Foster Care Outcomes: The Role of Contact. Journal of Social Service Research, 43(5), 533-546. https://doi.org/10.1080/01488376.2017.1340392

Fawley-King, K., Trask, E. V., Zhang, J., \& Aarons, G. A. (2017). The impact of changing neighborhoods, switching schools, and experiencing relationship disruption on children's adjustment to a new placement in foster care. Child Abuse \& Neglect, 63, 141-150. https://doi.org/10.1016/j.chiabu.2016.11.016

Fuentes, M. J., Bernedo, I. M., Salas, M. D., \& García-Martínet, M. A. (2018). What do foster families and social workers think about children's contact with birth parents? A focus group analysis. International Social Work, 62(5), 1416-1430. https://doi.org/10.1177/0020872818775475

Höjer, I. (2009). Birth parents' perception of sharing the care of their child with foster carers. Vulnerable Children and Youth Studies, 4(2), 161-168. https://doi.org/10.1080/17450120903012941

Howe, D., \& Steele, M. (2004). Contact in Cases in which Children have been Traumatically Abused or Neglected by their Birth Parents. In Neil, E. \& Howe, H. (eds.) Contact in Adoption and Permanent Foster Care (pp. 203-223). London: British Association for Adoption \& Fostering.

Instituto da Segurança Social. (2017). CASA 2016 - Caracterização Anual da Situação de Acolhimento das Crianças e Jovens [Annual characterisation of Children and Young People Foster Care Situation]. Lisboa: Instituto da Segurança Social.

Jiménez, J., \& Palacios, J. (2009). Acogimiento familiar en Andalucía. Procesos familiares, perfiles personales [Foster care in Andalusia. Family processes, personal profiles]. Sevilla: Consejería para la Igualdad y Bienestar Social. Junta de Andalucía.

López, M., \& Del Valle, J. (2016). Foster carer experience in Spain: Analysis of the vulnerabilities of a permanent model. Psicothema, 28(2), 122-129.

López, M., Montserrat, C., Del Valle, J., \& Bravo, A. (2010). El acogimiento en familia ajena en España. Una evaluación de la práctica y sus resultados [Non-relative family foster care in Spain: An assessment of practice and outcomes]. Infancia y Aprendizaje, 33(2), 269-280. https://doi.org/10.1174/021037010791114616

Martín, M. (1996). Adaptación para nuestro medio de la escala de sobrecarga del cuidador de Zarit (Adaptation for our environment of the overload scale of the caregiver of Zarit]. Revista Multidisciplinar de Gerontología, 6(4), 338-346.

McWey, L., Acock, A., \& Porter, B. (2010). The impact of continued contact with biological parents upon the mental health of children in foster care. Children and Youth Services Review, 32(10), 1338-1345. https://doi.org/10.1016/j.childyouth.2010.05.003

Ministerio de Sanidad, \& Servicios Sociales e Igualdad. (2017). Boletín de datos estadísticos de medidas de protección a 
la infancia [Child Protection Measures Statistical Bulletin]. Madrid: Secretaría de Estado de Servicios Sociales e Igualdad.

Morrison, J., Mishna, F., Cook, C., \& Aitken, G. (2011). Access visits: Perceptions of child protection workers, foster carers and children who are Crown wards. Children and Youth Services Review, 33(9), 1476-1482. https://doi.org/10.1016/j.childyouth.2011.03.011

Neil, E., \& Howe, D. (2004). Conclusions: a transactional model for thinking about contact. In Neil, E. \& Howe, D. (eds.) Contact in Adoption and permanent Foster Care (pp. 224-254). London: British Association for Adoption \& Fostering.

Ofsted. (2009). Keeping in Touch. A report of children's experience by the Children's Rights Director for England. Retrieved from http://www.ofsted.gov.uk/Ofsted-home/Publications-andresearch/Browse-all-by/Care/Children-s-rights/Keeping-in touch/(language)/eng-GB

Osborn, A., \& Delfabbro, P. (2009). Foster carers perceptions of the effects of parental contact upon children's psychosocial wellbeing in long-term foster care. Communities, Children and Families Australia, 4(2), 18-33.

Salas, M. D., Fuentes, M. J., Bernedo, I. M., \& García-Martín, M. G. (2016). Contact visits between foster children and their birth family: The views of foster children, foster carers and social workers. Child \& Family Social Work, 21(4), 473-483. https://doi.org/10.1111/cfs.12163

Sen, R., \& Broadhurst, K. (2011). Contact between children in out-of-home placements and their family and friends' networks: a research review. Child and Family Social Work, 16(3), 298-309. https://doi.org/10.1111/j.1365-2206.2010.00741.x

Sen, R., \& McCormack, J. (2011). Foster Carers' Involvement in Contact: Other Professionals' Views. Practice: social work in action, 23(5), 279-292. https://doi.org/10.1080/09503153.2011.611304

Sequeira, C. A. C. (2010). Adaptação e validação da Escala de Sobrecarga do Cuidador de Zarit [Adaptation and validation of Zarit Burden Interview Scale]. Revista Referência, 2(12), 9-16.

Sinclair, I. (2005). Fostering Now. Messages from research. London: Jessica Kingsley Publishers.

Ward, H., Munro, E., \& Dearden, C. (2006). Babies and young children in care. Life pathways, decision-making and practice. London: Jessica Kingsley Publishers.

Whiting, J., \& Lee, R. (2003). Voices from the system: A qualitative study of foster children's stories. Family Relations, 52(3), 288-295. https://doi.org/10.1111/j.1741-3729.2003.00288.x

Zarit, S. H., \& Zarit J. M. (1990). The memory and behavior problem checklist and the burden interview. Gerontology Center: Penn State University.

Zarit, S. H., Reever, K. E., \& Bach-Peterson, J. (1980). Relatives of the impaired elderly: correlates of feelings of burden. The Gerontologist, 20(6), 649-655. https://doi.org/10.1093/geront/20.6.649

\section{Copyrights}

Copyright for this article is retained by the author(s), with first publication rights granted to the journal.

This is an open-access article distributed under the terms and conditions of the Creative Commons Attribution license which permits unrestricted use, distribution, and reproduction in any medium, provided the original work is properly cited. 